\title{
Investigation of the Effects of Edaravone on Valproic Acid Induced Tissue Damage in Pancreas
}

Sehkar Oktay, Burçin Alev-Tüzüner, Sevim Tunalı, Esin Ak, Ebru Emekli-Alturfan, Tuğba Tunalı-Akbay, Leyla Koç-Öztürk, Şule Çetinel, Refiye Yanardağ, Ayşen Yarat

\begin{abstract}
Valproic acid (VPA), an effective antiepileptic and anticonvulsant drug, has some toxic side effects due to causing elevated oxidant production. The aim of this study is to investigate the effects of edaravone, a potent free radical scavenger on VPA induced toxicity and tissue damage by biochemical and histological examinations on pancreas. Female Sprague Dawley rats were divided into four groups as follows; control, edaravone, VPA, VPA+edaravon. VPA and edaravone were injected intraperitonally for seven days. Total protein, lipid peroxidation (LPO), sialic acid (SA) and glutathione (GSH) levels and alkaline phosphatase (ALP), tissue factor (TF), superoxide dismutase (SOD), glutathione-S-transferase
\end{abstract}

(GST), catalase (CAT), glutathione peroxidase (GPx) and myeloperoxidase (MPO) activities were determined in pancreas homogenates. In VPA given group, LPO and SA levels, and ALP, TF, MPO activities significantly increased and GST, CAT, GPx activities significantly decreased compared to control group. A marked morphological damage was detected in the VPA group. Ameliorative effects of edaravone were observed in SA, TF, CAT, GPx parameters and histological examination in the VPA group. Therefore, edaravone may be effective in moderation and/or reduction of toxic effects of VPA on pancreas.

Keywords: Valproic acid; edaravone; pancreas; tissue damage; antioxidant and oxidant parameters
Sehkar Oktay, Burcin Alev-Tuzuner, Ebru Emekli-Alturfan, Tugba TunaliAkbay, Leyla Koc-Ozturk, Aysen Yarat

Department of Biochemistry, Faculty of Dentistry, Marmara University, 34854, Maltepe, Istanbul, Turkey

Sevim Tunali, Refiye Yanardag

Department of Chemistry, Faculty of Engineering, Istanbul University, 34320, Avcilar, Istanbul, Turkey

Esin Ak

Department of Histology and Embryology, Faculty of Dentistry, Marmara University, 34854, Maltepe, istanbul, Turkey

Sule Cetinel

Department of Histology and Embryology, Faculty of Medicine, Marmara University, 34854, Maltepe, Istanbul

Corresponding Author:

Sehkar Oktay

e-mail:nsehkar@yahoo.com,ayarat@marmara.edu.tr

Submitted / Gönderilme: 16.01.2017 Revised / Düzeltme: 27.03.2017

Accepted / Kabul: 27.03.2017

\section{INTRODUCTION}

Epilepsy and seizures, which are more common than most disorders of the nervous system, affect approximately 70 million people worldwide. With approximately 200.000 new cases each year, research in this area is still active $(1,2)$. Valproic acid (2- $n$-propylpentanoic acid; VPA) and its salts, mainly sodium valproate, are effective antiepileptic and anticonvulsant drugs. Although VPA therapy has been used for the conditions such as generalized epilepsy, migraine and neuropathic pain, bipolar disorder. Reversible or irreversible side effects were reported mainly in liver, kidneys, pancreas, central nervous system, and hemopoietic system in the previous studies (3-5).

Acute pancreatitis associated with VPA therapy is a serious complication of VPA therapy and an idiosyncratic event. The VPA-induced acute pancreatitis has been suggested to occur as a result of the toxic effects of free radicals on the pancreatic cell membrane (3). The various effects of antiepileptic drugs such as carbamazepine, phenobarbital, topiramate and 
especially VPA on the antioxidant system have been studied (6), but the mechanism of the VPA toxicity has not been cleared yet, especially in pancreatic tissue. These antiepileptic drugs may trigger oxygen-dependent tissue injury by several mechanisms and resulting elevated free radical production and toxicity in the body and can cause various symptoms such as anorexia, nausea, vomiting and diseases such as jaundice, coagulation disorders and also fatality $(4,5)$.

Edaravone (3-methyl-1-phenyl-2-pyrazolin-5-one) is a potential scavenger of hydroxyl radicals and used as a neuroprotective agent for the treatment of acute cerebral infarction with acute ischemic stroke (6). In various studies it was suggested that edaravone has anti-apoptotic, antinecrotic, anti-inflammatory effects and may prevent oxidative stress-induced cell injuries and tissue damage by scavenging free radicals and inhibiting lipid peroxidation (LPO) $(7,8)$. For that reason, using edaravone in VPA treatment may be effective to avoid tissue damage due to toxic effects of VPA.

The aim of the present study is to investigate the effects of VPA on oxidant and antioxidant balance and inflammation markers and to investigate the potential therapeutic effect of edaravone on oxidative stress and tissue damage in pancreas.

\section{MATERIAL and METHODS}

All experimental protocols of the study were approved by the Marmara University Animal Care and Use Committee (134.2013mar). Animals were kept in routine laboratory conditions. The experiment was performed according to our previous dose response studies. Thirty seven Sprague Dawley female rats were divided into four groups as follows; control group $(\mathrm{n}=8)$, edaravone $\left(30 \mathrm{mgkg}^{-1} \mathrm{day}^{-1}\right)$ given group $(\mathrm{n}=8)$, VPA $\left(0.5 \mathrm{gkg}^{-1} \mathrm{day}^{-1}\right)$ given group $(\mathrm{n}=10)$, VPA+edaravone (30 mg kg-1 day ${ }^{-1}$ ) given group $(n=11)$. Edaravone and/or VPA were given intraperitoneally for 7 days and VPA was given to the animals $1 \mathrm{~h}$ later than the edaravone dose.

On the $8^{\text {th }}$ day of the experiment, animals were fasted overnight and sacrificed under anesthesia. Pancreatic tissues were taken, homogenized in physiological saline and $10 \%$ $(\mathrm{w} / \mathrm{v})$ homogenates were prepared. Total protein, LPO, sialic acid (SA) and glutathione (GSH) levels and alkaline phosphatase (ALP), tissue factor (TF), superoxide dismutase (SOD), glutathione-S-transferase (GST), catalase (CAT), glutathione peroxidase (GPx) and myeloperoxidase (MPO) activities were determined in pancreas homogenates.

\section{Determination of protein}

Total protein levels of pancreas were determined by the method of Lowry (9). Briefly, in alkali medium proteins are reacted with copper ions and reduced by Folin reactive. The absorbance was evaluated at $500 \mathrm{~nm}$. By using bovine serum albumin as a standard, total protein levels of pancreas tissues were calculated to express the results of the parameters per protein.

\section{Determination of LPO}

Malondialdehyde (MDA), one of the products of LPO in tissues, was determined as thiobarbituric acid reactive substances according to the method of Yagi (10). LPO was expressed in terms of MDA equivalents using the extinction coefficient of $1.56 \times 10^{5} \mathrm{M}^{-1} \mathrm{~cm}^{-1}$. Results were expressed as $\mathrm{nmol} \mathrm{MDA} / \mathrm{mg}$ protein.

\section{Determination of $S A$}

SA levels of pancreas were determined by the thiobarbituric acid method of Warren (11). Homogenates were incubated with $0.1 \mathrm{~N}_{2} \mathrm{SO}_{4}$ at $80^{\circ} \mathrm{C}$ for 1 hour and hydrolysate was used for analysis. SA is oxidized with sodium periodate in concentrated phosphoric acid and the product of periodate oxidation is coupled with thiobarbituric acid, then the chromophore that formed is extracted into cyclohexanone. The absorbances of samples were measured at wavelength of $549 \mathrm{~nm}$ and the results were expressed as $\mathrm{mg} \mathrm{SA} / \mathrm{g}$ protein.

\section{Determination of GSH}

GSH levels were determined in pancreas according to the method of Beutler (12) by using metaphosphoric acid for protein precipitation and 5,5'-Dithiobis-2-nitrobenzoic acid for color development. The extinction coefficient of $1.36 \times 10^{4}$ $\mathrm{M}^{-1} \mathrm{~cm}^{-1}$ was used for calculation of GSH levels of pancreas tissues and results were expressed as $\mathrm{mg} \mathrm{GSH} / \mathrm{g}$ protein.

\section{Determination of ALP activity}

ALP activity of pancreas tissues were determined according to the method of Walter and Schült (13). Depending on the $\mathrm{pH}$ of the medium, ALP hydrolyzes p-nitrophenyl phosphate to $\mathrm{p}$-nitrophenol. The absorbances of samples at $405 \mathrm{~nm}$ were recorded and ALP activities were expressed as $U$ / g protein. 


\section{Determination of TF activity}

TF activities of pancreas tissues were determined by Quick's one-stage method (14). Pooled plasma collected from healthy subjects was used and all reagents were brought to $37^{\circ} \mathrm{C}$, which is the reaction temperature, before admixture. TF activity of pancreas tissue was performed by mixing $0.1 \mathrm{ml}$ homogenate with $0.1 \mathrm{ml}$ of plasma, then the clotting reaction was started by the addition of $0.1 \mathrm{ml}$ of $0.02 \mathrm{M} \mathrm{CaCl}_{2}$. The clotting time is inversely proportional to the TF activity, for that reason the increase in the clotting time is a manifestation of decreased TF activity.

\section{Determination of SOD activity}

SOD activities were determined by the method based on the ability of SOD to increase the effect of riboflavin-sensitized photo-oxidation of o-dianisidine (15). The activity of superoxide is generated by illuminating the reaction mixture which contains $o$-dianisidine dihydrochloride and riboflavin by light of a fluorescent lamp. The oxidation of o-dianisidine, as sensitized by riboflavin, is enhanced by SOD and the increase is linearly dependent on SOD concentration. The absorbance of the colored product was quantified with spectrophotometer at $460 \mathrm{~nm}$. Absorbances at 0 and $8^{\text {th }}$ minutes of illumunation were measured and the net absorbance was calculated. Bovine SOD (Sigma Chemical Co, S2515-3000 U) was prepared as reference and the results were expressed in $\mathrm{U} / \mathrm{mg}$ protein.

\section{Determination of GST activity}

GST catalyzes the conjugation of GSH. The absorbance of mixture at $25^{\circ} \mathrm{C}$ is measured by spectrophotometer at 340 $\mathrm{nm}$. GST activities of pancreas tissues were calculated by using the extinction coefficient of $9.6 \mathrm{mM}^{-1} \mathrm{~cm}^{-1}$ and results were expressed as U/g protein (16).

\section{Determination of CAT activity}

CAT activities of the pancreas tissues were determined by the method of Aebi (17) which is based on the conversion of hydrogen peroxide $\left(\mathrm{H}_{2} \mathrm{O}_{2}\right)$ to water by the effect of CAT enzyme. This conversion was observed as a decrease in absorbance measured at $240 \mathrm{~nm}$ and CAT activity of samples were given as $\mathrm{U} / \mathrm{mg}$ protein.

\section{Determination of GPx activity}

GPx activity of the pancreas tissues were determined by the method of Paglia and Valentine (18). The conversion of $\mathrm{H}_{2} \mathrm{O}_{2}$ to water is catalyzed by GPx. The generated glutathione disulfide is reduced to GSH with consumption of NADPH by glutathione reductase. The decreasing in absorbance during the oxidation of NADPH to NADP was measured spectrophotometrically at $366 \mathrm{~nm}$. The extinction coefficient of $6.22 \mathrm{mM}^{-1} \mathrm{~cm}^{-1}$ was used for calculation and results were given as $\mathrm{U} / \mathrm{g}$ protein.

\section{Determination of MPO activity}

MPO is found in the primary granules of neutrophils. Enzymatic activity of MPO was determined by the method of Wei\&Frenkel (19) which contains a solution of tissue homogenate, phenol, $\mathrm{H}_{2} \mathrm{O}_{2}$ and 4-aminoantipyrine as color generating substance. One unit of enzyme activity was defined as the amount of the MPO present per gram of protein which caused a change in absorbance per minute at $460 \mathrm{~nm}$ and $37^{\circ} \mathrm{C}$. The results were expressed as $\mathrm{U} / \mathrm{g}$ protein.

\section{Histological examination}

For the light microscopic examination, pancreas tissue samples were fixed in $10 \%$ formalin, routinely processed and embedded in paraffin. Tissue sections $(5 \mu \mathrm{m})$ were stained with hematoxylin-eosin ( $\mathrm{H} \& \mathrm{E})$ for general morphology. All sections were investigated by an histologists unaware of the treatment groups and photographed with a digital camera (Olympus DP 72, Tokyo, Japan) attached to a photomicroscope (Olympus BX51, Tokyo, Japan).

\section{STATISTICS}

Statistical analysis was carried out using GraphPad Prism 5.0 (GraphPad Software, San Diego, USA). All data were expressed as mean \pm standard deviation. Kruskal Wallis test was used for the comparison of groups of data followed by Dunn's multiple comparison tests. Value of P less than 0.05 was regarded as significant.

\section{RESULTS}

\section{Levels of LPO, SA, GSH and activities of ALP and TF}

LPO, SA and GSH levels, ALP and TF activities of each group are shown in Table 1. LPO levels significantly increased in VPA group compared with control $(\mathrm{p}<0.05)$. In SA levels, a significant increase $(\mathrm{p}<0.05)$ was detected in VPA group compared with control and a significant decrease $(\mathrm{p}<0.05)$ was detected in VPA+edaravone group compared with VPA 
Table 1. Levels of LPO, SA, GSH and activities of ALP and TF in pancreas in control and experiment groups ${ }^{\ddagger}$.

\begin{tabular}{ccccc} 
& $\begin{array}{c}\mathrm{C} \\
(\mathbf{n}=\mathbf{8})\end{array}$ & $\begin{array}{c}\mathrm{E} \\
(\mathbf{n}=\mathbf{8})\end{array}$ & $\begin{array}{c}\text { VPA } \\
(\mathbf{n}=\mathbf{1 0})\end{array}$ & $\begin{array}{c}\text { VPA+E } \\
(\mathbf{n}=\mathbf{1 1})\end{array}$ \\
\hline LPO(nmolMDA/mg p) & $2.28 \pm 0.77$ & $2.45 \pm 0.89$ & $2.93 \pm 1.13^{*}$ & $2.38 \pm 0.73$ \\
SA (mg/g p) & $9.87 \pm 0.65$ & $9.76 \pm 0.78$ & $11.00 \pm 1.09^{*}$ & $10.07 \pm 0.82^{\mathrm{a}}$ \\
GSH ( $\mathbf{m g} / \mathbf{g} \mathbf{p})$ & $4.38 \pm 1.02$ & $4.21 \pm 0.91$ & $3.85 \pm 0.54$ & $3.59 \pm 1.20$ \\
ALP (U/g p) & $1.41 \pm 0.33$ & $2.10 \pm 0.53$ & $2.36 \pm 0.32^{* * *}$ & $2.30 \pm 0.91^{\star}$ \\
TF activity (second) & $185.5 \pm 16.75$ & $169.1 \pm 17.39$ & $148.7 \pm 11.84^{* * *}$ & $173.8 \pm 30.11^{\text {aa }}$
\end{tabular}

*Values are given as mean \pm standard deviation

LPO: lipid peroxidation; SA: sialic acid, GSH: glutathione peroxidase; ALP: alkaline phosphatase; TF: tissue factor, MDA: malondialdehyde; p: protein; C: control, E: edaravone; VPA: valproic acid.

Lengthening in seconds of TF activity is a manifestation of decreased activity.

${ }^{*} \mathrm{p}<0.05,{ }^{* *} \mathrm{p}<0.001$ vs group $\mathrm{C}$

${ }^{\mathrm{a}} \mathrm{p}<0.05,{ }^{\text {aa }} \mathrm{p}<0.01$ vs group VPA

group. The decreases observed in the GSH levels of VPA and VPA+edaravone groups were unsignificant. ALP activity significantly increased both in VPA and VPA+edaravone groups compared with control $(\mathrm{p}<0.001, \mathrm{p}<0.05)$. TF activity increased significantly $(\mathrm{p}<0.001)$ in VPA group compared with control and decreased significantly $(\mathrm{p}<0.01)$ in VPA+edaravone group compared with VPA.

\section{Activities of SOD, GST, CAT, GPX and MPO}

Activities of SOD, GST, CAT, GPx and MPO of each groups are shown in Table 2. No significant difference was detected in SOD activity. Both in VPA and VPA+edaravone groups, GST activity significantly decreased $(\mathrm{p}<0.05, \mathrm{p}<0.01)$ compared with control and also, in VPA+edaravone group a significant decrease $(\mathrm{p}<0.01)$ was found compared with edaravone group. CAT activity significantly decreased $(p<0.001)$ in VPA group compared with control and significantly increased $(\mathrm{p}<0.001)$ in VPA+edaravone group compared with VPA group. A significant decrease $(\mathrm{p}<0.01)$ was detected in GPx activity of VPA group compared with control and a significant increase $(p<0.01)$ was found in VPA+edaravone group compared with VPA group. MPO activity increased significantly $(\mathrm{p}<0.05)$ in VPA group compared with control and also increased significantly $(\mathrm{p}<0.05)$ in VPA+edaravone group compared with edaravone group.

Table 2. Activities of SOD, GST, CAT, GPx and MPO in pancreas in control and experimental groups ${ }^{\ddagger}$.

\begin{tabular}{ccccc} 
& $\begin{array}{c}\mathrm{C} \\
(\mathbf{n}=\mathbf{8})\end{array}$ & $\begin{array}{c}\mathrm{E} \\
(\mathbf{n}=\mathbf{8})\end{array}$ & $\begin{array}{c}\text { VPA } \\
(\mathbf{n}=\mathbf{1 0})\end{array}$ & $\begin{array}{c}\text { VPA+E } \\
(\mathbf{n}=\mathbf{1 1})\end{array}$ \\
\hline SOD (U/mg p) & $4.87 \pm 2.33$ & $4.90 \pm 3.26$ & $4.76 \pm 1.32$ & $5.34 \pm 1.24$ \\
GST (U/g p) & $38.22 \pm 6.08$ & $37.81 \pm 5.28$ & $29.69 \pm 5.01^{*}$ & $28.87 \pm 3.95^{* * \text { ee }}$ \\
CAT ( U/mg p) & $136.2 \pm 17.66$ & $129.0 \pm 25.61$ & $107.2 \pm 11.07^{* * *}$ & $131.0 \pm 14.52^{\text {aaa }}$ \\
GPx (U/g p) & $175.9 \pm 31.82$ & $170.0 \pm 34.33$ & $123.4 \pm 12.20^{* *}$ & $187.9 \pm 45.79^{\text {aa }}$ \\
MPO (U/g p) & $6.69 \pm 0.59$ & $6.64 \pm 0.40$ & $7.94 \pm 1.00^{*}$ & $7.25 \pm 0.70^{\text {e }}$
\end{tabular}

*Values are given as mean \pm standard deviation SOD: superoxide dismutase; GST: glutathione-S-transferase; CAT: catalase; GPx: glutathione peroxidase; MPO: myeloperoxidase; p: protein; C: control, E: edaravone; VPA: valproic acid.

${ }^{*} \mathrm{p}<0.05,{ }^{* *} \mathrm{p}<0.01,{ }^{* *} \mathrm{p}<0.001$ vs group $\mathrm{C}$

${ }^{\text {aa }} \mathrm{p}<0.01$, aаa $\mathrm{p}<0.001$ vs group VPA

${ }^{\mathrm{e}} \mathrm{p}<0.05,{ }^{\mathrm{ee}} \mathrm{p}<0.01$ vs group $\mathrm{E}$ 


\section{Histological examination of pancreas tissue}

Light microscopic evaluation of the experimental groups is shown in Figure 1. Control group showed a regular morphology with acinar structures and Langerhans islets (Figure 1A). There was no significant morphological difference between edaravone (Figure 1B) and control groups. In the VPA group, vacuolization in cytoplasm of acinar cells, eosinophilic fibrillar cytoplasm in some acinar cells and degeneration of Langerhans islets were the prominent features of the morphologic damage (Figure 1C). In VPA+edaravone group, besides the reduced but ongoing vacuolar structures, morphological regeneration of acinar cells and Langerhans islets was prominent (Figure 1D).
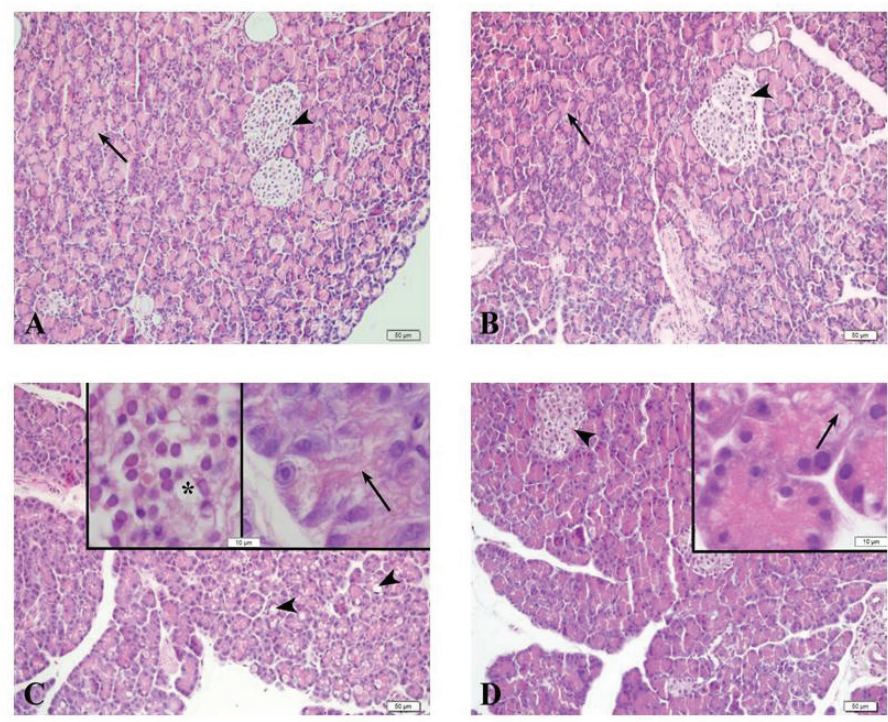

Figure 1. Control group: regular morphology with acinar structures (arrow) and Langerhans islets (arrowhead) (A). Edaravone given group: similar morphology with control group, Langerhans islets (arrowhead), acinar structures (arrow) (B). Valproic acid given group: acinar cell degeneration with cytoplasmic vacuolization (arrowhead), eosinophilic fibrillar cytoplasm (arrow) and degeneration of Langerhans islets (asterix) (C). Valproic acid+edaravone given group: regeneration of acinar (arrow) and Langerhans islets (arrow head) morphology (D). H\&E staining.

\section{DISCUSSION}

Pancreas is a digestive organ that also acts as an important endocrine gland producing several hormones. In the present study, increased levels of LPO and SA, also increased activities of ALP and MPO, decreased activities of GST, CAT, GPx were found in VPA given group compared with control group. The decrease in GSH level and SOD activity was unsignificant. Edaravone was effective in eliminating the harmful effects of VPA by decreasing SA level and TF activity and increasing CAT and GPx activities. Also morphological damage was observed in histological examination of pancreas tissue of VPA group.

In previous studies, it was reported that antiepileptic drugs, especially VPA, trigger tissue injury and increase the production of reactive oxygen species by several mechanism and have diverse effects on defence system $(20,21)$. There are many studies that show the elevation of LPO levels in blood and tissues under VPA treatment $(20,22,23)$. An increase in the peroxidation of membrane lipids may cause excessive production of free radicals and suppression of immune defence system or decrease the activities of antioxidant enzymes. LPO starts with the production of lipid radical in the cell. As VPA, is a fatty acid derivative, it elevates free radical production, thus VPA may cause an unavoidable increase in LPO. In the present study, increased LPO in VPA treated group is an evidence of pancreas damage and toxicity due to the elevated free radical production. Edaravone administration decreased LPO level in VPA treated group. Although the result was unsignificant, the decrease in LPO might be due to the antioxidant effect of edaravone on pancreatic tissue as edaravone as a synthetic antioxidant has been reported to be an ubiquitously acting direct free radical scavenger that inhibits lipoxygenase activity while being highly efficient in detoxifying the devastating reactive hydroxyl radicals and also directly neutralizing peroxyl radicals (24).

SA is a monosaccharide with a nine-carbon backbone and plays an important role in many neuronal processes. Increased levels of SA is a marker for several diseases caused by inflammation. For that reason, it was suggested SA is a self-protection of organism (25) and increased levels of SA in VPA given group may be a sign of inflammatory effect of VPA. A decrease in SA level was observed in VPA+edaravone group versus VPA group that may be due to the protective effect of edaravone against inflammatory effect of VPA. Lipoxygenases are defined as non-heme iron containing enzymes catalyzing the integration of molecular oxygen in polyunsaturated fatty acids. Nowadays lipoxygenase family members have received attraction because of their relation with inflammation and atherosclerosis (26). On the other hand, edaravone has been shown to inhibit lipoxygenase 
activity (26) therefore it may be suggested as an effective agent in suppression of inflammation in pancreas.

Epilepsy and bipolar diseases require long term or/and lifelong treatment, for that reason the continuous and long term use of VPA may cause some potential adverse effects, such as low bone mineral density which causes tendency of osteoporosis and osteopenia. Additionally, in previous studies VPA has been suggested as a cytochrome P450 enzyme inhibitor with multiple effects on bone (27). VPA therapy may cause an increase in serum calcium concentrations and bone resorption (28). Voudris et al. investigated different kinds of antiepileptics and reported increased activity of ALP enzymes in bone, kidney and intestine tissues in patients who had anticonvulsant monotherapy versus control group (29). Also Giray et al. (30) detected increased ALP activity in the serum samples of VPA treated patients. In the present study increased activity of ALP activity in pancreas tissue, which is an important enzyme for calcification, in VPA group supports this idea.

Tissue factor (TF) is a cell membrane component and the primary cellular initiator of blood coagulation system. Various tissues and body fluids have TF activity (31). Although blood coagulation disturbances are common in patients using VPA, they rarely become clinically symptomatic. In literature controversy exists about the clinical relevance of the haematological abnormalities of VPA treatment which can cause a variety of laboratory abnormalities affecting haemostasis (32). VPA therapy has also been shown to affect bone marrow and reduce platelet and red blood cell counts (33).

In the present study, TF activity has been used as an indicator of tissue damage in VPA treatment and a significant increase was detected in VPA treated group whereas edaravone administration decreased TF activity in this group. This may indicate the therapeutic role of edaravone as decreased TF activity may have importance in practice in terms of reducing the risk of thrombosis in patients using VPA.

The mechanism of VPA in tissue toxicity is still a complex and unclear situation yet. There are conflicting results about antioxidant parameters in VPA treatment, but the researchers agreed overall that VPA causes an increase in trace element clearance and affects functioning of free radical scavenging enzymes. Therefore, administration of VPA induced suppressing activity on the immune system and antioxidant enzymes that may contribute to the development of organ toxicity and dysfunction (34). Płonka-Półtorak et al. (35) found higher SOD activities in plasma and erythrocyte of patients treated with VPA. Whereas, Vidya and Subramanian (36) found decreased activities of antioxidant enzymes such as SOD, GPx and CAT in the liver and kidney tissues of rats treated with sodium valproate. Espandiari et al. (37) showed morphological alterations in their study with VPA by light microscopic examination in the kidney and spleen tissue. Tung and Winn (21) mentioned increased production of reactive oxygen species in their VPA study with wholeembryo culture. In accordance with these results, in the present study, we found decreased antioxidant enzyme activities in VPA group which is an evidence of oxidative damage. Administration of edaravone elevated activities of antioxidant enzymes such as CAT and GPx in VPA given groups. Also, in edaravone given VPA group SOD activity increased but the result was unsignificant. These antioxidant enzymes are important defence systems against toxic effects of free radicals and detoxification of $\mathrm{H}_{2} \mathrm{O}_{2}$. The elevation of activities of these enzymes might be due to defence metabolism of the cell and edaravone has been effective in supporting defence system by acting as direct free radical scavenger detoxifying and neutralizing radicals (24).

In the present study, VPA induction led to vacuolization in the cytoplasm of acinar cells, eosinophilic fibrillar cytoplasm in some acinar cells and degeneration of Langerhans islets revealed by light microscopic examination of the pancreas tissue. Vacuolization and eosinophilic fibrillar pattern in acinar cell cytoplasms might be potential factors for digestion physiology. Likewise, degenerated Langerhans islets seen in rats given VPA may cause abnormal release of insulin and glucagon, thereby causing dysfunction in carbohydrate metabolism. Although the exact mechanism is unknown, tissue damage could be a result by the excess of free radical and LPO $(38,39)$. In VPA+edaravone group, besides the reduced but ongoing vacuolar structures, regeneration of acinar cells and Langerhans islets morphology was prominent. Protective effect of edaravone on both acinar and Langerhans cells could be explained by its antioxidant effect.

In conclusion, our results demonstrate that VPA may lead to an imbalance in the oxidant-antioxidant status of pancreas. VPA treatment caused morphological pancreatic injury and oxidative stress markers in the present study. Edaravone which is known as a protective agent, may be useful in moderation or reduction of deleterious effects of VPA on pancreas. Although statistically unsignificant, edaravone reduced LPO level and MPO activity in pancreas as a sign of decreased oxidative injury. Furthermore histological analysis revealed that edaravone prevented inflammatory process. Edaravone protects tissues by eliminating free radicals and 
inhibiting the initiation and progression of oxidative damage induced by $\mathrm{H}_{2} \mathrm{O}_{2}$ radicals by interacting with both peroxyl and hydroxyl radicals. Edaravone may be suggested to be useful for preventing inflammatory and oxidative reactions due to the deleterious effects of VPA administration in pancreas.

\section{CONFLICT of INTEREST}

The authors have no conflict of interest.

\section{Valproik Asit İle Oluşturulan Pankreas Hasarında Edaravanun Etkisinin İncelenmesi}

\section{ÖZ}

Antiepileptik ve antikonvülzan etkili bir ilaç olan valproik asit (VPA) oksidan üreminde artışa neden olduğundan toksik yan etkilere sahiptir. Bu çalışmanın amacı güçlü bir serbest radikal yakalayıcısı olan edaravonun VPẢnın yol açtığı toksisite ve doku hasarı üzerine etkilerini biyokimyasal ve histolojik olarak araştırmaktır. Dişi Spraque Dawley türü sıçanlar kontrol, edaravon (30 mg kg-1 gün-1), VPA (0.5 mg kg-1 gün1), VPA+edaravon (aynı dozlarda) olmak üzere dört gruba ayrıld. VPA ve edaravon intraperitonal olarak 7 gün boyunca verildi. Total protein, lipit peroksidasyon (LPO), siyalik asit (SA) ve glutatyon (GSH) düzeyleri ve alkalen fosfataz (ALP), doku faktörü (DF), süperoksit dismutaz (SOD), glutatyonS-transferaz (GST), katalaz (KAT), glutatyon peroksidaz (GPx) ve miyeloperoksidaz (MPO) aktiviteleri pankreas homojenatlarında ölçüldü. LPO ve SA düzeyleri ve ALP, DF ve MPO aktiviteleri kontrol grubuna göre kıyaslandığında VPA grubunda anlamlı olarak arttı. GST, KAT ve GPx aktiviteleri kontrol grubuna göre kıyaslandığında VPA grubunda anlamlı olarak azaldı. VPA grubunda morfolojik olarak belirgin bir hasar tespit edildi. Edaravonun olumlu etkisi SA, DF, KAT ve GPx parametrelerinde ve histolojik incelemede gözlemlendi. $\mathrm{Bu}$ nedenle, edaravon VPA’nın pankreastaki zararlı etkilerinin giderilmesinde ve/veya azaltılmasında yararlı olabilir..

Anahtar Kelimeler: Valproik asit; edaravon; pankreas; doku hasarı; antioksidan ve oksidan parametreler

\section{REFERENCES}

1. Iasemidis LD. Seizure prediction and its application. Neurosurg Clin N Am 2011; 22: 489-506.

2. Brodie MJ, Barry SJE, Bamagous GA, Norrie JD, Kwan P. Patterns of treatment response in newly diagnosed epilepsy. Neurology 2012; 78: 1548-54.

3. Gerstner T, Büsing D, Bell N, Longin E, Kasper JM, Klostermann W, Hebing B, Hanefeld F, Eckel U, Hoffman $\mathrm{R}$, Bettendorf U, Weidner B, Wiemer-Kruel A, Brockmann K, Neumann FW, Sandriese T, Wolff M, König S. Valproic acid-induced pancreatitis: 16 new cases and a review of the literature. J Gastroenterol 2007; 42: 39-48.

4. Perucca P, Gilliam FG. Adverse effects of antiepileptic drugs. Lancet Neur 2012; 11: 792-802.

5. Belcastro V, D’Egidio C, Striano P, Verrotti A. Metabolic and endocrine effects of valproic acid chronic treatment. Epilepsy Res 2013; 107: 1-8.

6. Adams HP Jr, del Zoppo G, Alberts MJ, Bhatt DL, Brass L, Anthony F, Grubb RL, Higashida RT, Jauch EC, Kidwell C, Lyden PD, Morgenstern LB, Qureshi AI, Rosenwasser RH, Scott P, Wijdicks EFM. Guidelines for the early management of adults with ischemic stroke. Stroke 2007; 38: 1655-711.

7. Xi H, Akishita M, Nagai K, Yu W, Hasegawa H, Eto M, Kozaki K, Toba K. Potent free radical scavenger, edaravone, suppresses oxidative stress-induced endothelial damage and early atherosclerosis. Atherosclerosis 2007; 191: 281-9.

8. Kikuchi K, Tancharoen S, Takeshiga N, Yoshitomi M, Morioka M, Murai Y, Tanaka E. The efficacy of edaravone (radicut), a free radical scavenger, for cardiovascular disease. Int J Mol Sci 2013; 14: 13909-30.

9. Lowry $\mathrm{OH}$, Rosebrough NJ, Farr AL, Randall RJ. Protein measurement with the Folin phenol reagent. J Biol Chem 1951; 193; 265-75.

10. Yagi K. Assay for blood plasma or serum. Methods Enzymol 1981; 105: 328-37.

11. Warren L. The thiobarbituric acid assay of sialic acids. J Biol Chem 1959; 234: 1971-5.

12. Beutler E. Gluthatione: red cell metabolism. A manual biochemical methods. New York: Grune and Stratton, 1975, pp:112-14.

13. Walter K, Schült C. Acid and alkaline phosphatase in serum (two point method) In Methods of enzymatic Analysis Ed: Bergmeyer HU, 2nd ed. FL, 1974, pp:856-86.

14. Ingram GIC, Hills M. Reference method for the one stage prothrombin time test on human blood. Thromb Haemostas 1976; 36: 237-8.

15. Mylorie AA, Collins H, Umbles C, Kyle J. Erythrocyte SOD activity and other parameters of copper status in rats ingesting lead acetate. Toxicol Appl Pharmacol 1986; 82: 512-20.

16. Habig WH, Jacoby WB. Assays for differentation of glutathione-S-transferases. Methods in Enzymol 1981; 77: 398-405.

17. Aebi H. Catalase in vitro. Methods Enzymol 1984; 105: 121-6.

18. Paglia DE, Valentine WN. Studies on the quantitative and quantitative characterization of erythrocyte glutathione peroxidase. J Lab Clin Med 1967; 70: 158-68. 
19. Wei H, Frenkel K. In vivo formation of oxidized DNA bases in tumor promoter- treated mouse skin. Cancer Res 1991; 51: 4443-9.

20. Hamed SA, Abdellah MM, El-Melegy N. Blood levels of trace elements, electrolytes, and oxidative stress/antioxidant systems in epileptic patients. J Pharmacol Sci 2004; 96: 465-73.

21. Tung EY, Winn LM. Valproic acid increases formation of reactive oxygen species and induces apoptosis in postimplantation embryos: A role for oxidative stress in valproic acid-induced neural tube defects. Mol Pharmacol 2011; 80: 979-87.

22. Chaudhary S, Ganjoo P, Raiusddin S, Parvez, S. Nephroprotective activities of quercetin with potential relevance to oxidative stress induced by valproic acid. Protoplasma 2015; 252: 209-17.

23. Mittal K, Mehta P, Mittal A, Aggarwal HK. Valproate induced thrombocytopenia and renal dysfunction: Case report. IJPRR 2016; 5: 39-41.

24. Yamamoto Y, Kuwahara T, Watanabe K. Antioxidation activity of 3-methyl-1-phenyl-pyrazolin-5-one. Redox Rep 1996; 2: 333-8.

25. Varki A. Sialic acids in human health and disease. Trends Mol Med 2008; 14: 351-60.

26. Funk CD. Lipoxygenase pathways as mediators of early inflammatory events in atherosclerosis. Arterioscl Throm Vas 2006; 26: 1204-6.

27. Svalheim S, Røste LS, Nakken KO, Taubøll E. Bone health in adults with epilepsy. Acta Neurol Scand 2011; 124: 89-95

28. Sato Y, Kondo I, Ishida S, Motooka H, Takayama K, Tomita Y, Maeda H, Satoh K. Decreased bone mass and increased bone turnover with valproate therapy in adults with epilepsy. Neurology 2001; 14: 445-9.

29. Voudris K, Moustaki M, Zeis PM, Dimou S, Vagiakou E, Tsagris B, Skardoutsou A. Alkaline phosphatase and its isoenzyme activity for the evaluation of bone metabolism in children receiving anticonvulsant monotherapy. Seizure 2001; 11: 377-80.
30. Giray T, Vitrinel A, Comert S, Deniz NC, Erdag GC, Kesler E, Sadikoglu S, Akın Y. The evaluation of the effects of antiepileptic drugs on bone metabolism. Turk Arch Ped 2005; 40: 221-6.

31. Yarat A, Tunali T, Piririciler R, Akyuz S, Ipbuker A, Emekli N. Salivary thromboplastic activity in diabetic and healthy controls. Clin Oral Invest 2004; 8: 36-9.

32. Cannizzaro E, Albisetti M, Wohlrab G, Schmugge M. Severe bleeding complications during antiepileptic treatment with valproic acid in children. Neuropediatrics 2007; 38: 42-5.

33. Gidal B, Spencer N, Maly M, Pitterle M, Williams E, Collins $\mathrm{M}$, Jones J. Valproate mediated disturbances of hemostasis. Relationship to dose and plasma concentration. Neurology 1994; 44: 1418-22.

34. Graf WD, Oleinik OE, Glauser TA, Maertens P, Eder DN, Pippenger CE. Altered antioxidant enzyme activities in children with a serious adverse experience related to valproic acid therapy. Neuropediatrics 1998; 29: 195-201.

35. Płonka-Półtorak E, Zagrodzki P, Chłopicka J, Bartoń H, Westermarck T, Kaipainen P, Kaski M, Atroshi F. Valproic acid modulates superoxide dismutase, uric acid-independent FRAP and zinc in blood of adult epileptic patients. Biol Trace Elem Res 2011; 143: 1424-34.

36. Vidya M, Subramanian P. Effects of a-ketoglutarate on antioxidants and lipid peroxidation products in rats treated with sodium valproate. J Appl Biomed 2006; 4: 141-6.

37. Espandiari P, Laura JZ, Schnackenberg K, Miller TJ, Knapton A, Herman EH, Beger RD, Hanig JP. Age-related differences in susceptibility to toxic effects of valproic acid in rats. J Appl Toxicol 2008; 28: 628-37.

38. Moreiras M, Reguez E, Guina I. On the toxicity of valproic acid. Clin Nephrol 1990; 51: 187-9.

39. El-Deeb T. The effect of valproic acid on the pancreatic acini of the adult rats and the possible protective role of L-carnitine. Light, electron microscopy and DNA electrophoresis. Egyptian J Histol 2006; 29: 1-8. 